\title{
QbD-based Formulation Optimization and Characterization of Polymeric Nanoparticles of Cinacalcet Hydrochloride with Improved Biopharmaceutical Attributes
}

\section{Geliştirilmiş Biyofarmasötik Özelliklere Sahip Sinakalset Hidroklorürün Polimerik Nanopartiküllerinin QbD Tabanlı Formülasyon Optimizasyonu ve Karakterizasyonu}

\author{
(D) Debashish GHOSE ${ }^{1 *}$, (D) Chinam Niranjan PATRA¹, (D) Bera Varaha Venkata RAVI KUMAR¹, (D) Suryakanta SWAIN2, (D) Bikash Ranjan JENA3 , \\ (D) Punam CHOUDHURY1', (D) Dipthi SHREE1 \\ ${ }^{1}$ Roland Institute of Pharmaceutical Sciences, Berhampur (Affiliated to Biju Patnaik University of Technology, Rourkela), Odisha, India \\ 2Department of Pharmacy, School of Health Sciences, The Assam Kaziranga University, Jorhat, Assam, India \\ 3School of Pharmacy and Life Sciences, Centurion University of Technology and Management (CUTM), Bhubaneswar, Odisha India
}

\begin{abstract}
Objectives: The aim of the present work was to prepare $\mathrm{QbD}$ enabled optimization, and to improve the oral bioavailability of freeze-dried polymeric nanoparticles of cinacalcet hydrochloride manufactured by nanoprecipitation and ultrasonication methods using polymers PLGA, and poloxamer-188.

Materials and Methods: The initial screening and optimization were carried out for the formulations by employing Taguchi and Box-Behnken Designs. The FT-IR and DSC revealed no interactions and had no incompatibility among the selected drug and polymers. The nanoparticles were characterized for \% drug release, particle size analysis, zeta potential, PDI, SEM, TEM, P-XRD, TGA, DTA, in vitro, and in vivo drug release study.

Results: In vitro drug release study showed sustained release of the drug from the optimized batch by diffusion mechanism. The optimized nanoparticle formulation was recognized by numerical and graphical methods using validation of the experimental model. The optimized batch was stable as per the $\mathrm{ICH}$ stability guidelines for 6 months with no considerable alternation noticed in particle size, entrapment efficiency, and in vitro drug release. The pharmacokinetic parameters of AUC and Cmax data for the optimized formulation increased 3- and 2.9-folds compared to the pure-drug suspension.

Conclusion: The prepared polymeric nanoparticles formulation is an alternative delivery system for enhanced therapeutic efficacy and bioavailability potential of a model drug to manage long-term normocalcemia in patients with preliminary hyperparathyroidism.
\end{abstract}

Key words: PLGA, polymeric nanoparticles, Taguchi, P-XRD, optimization, bioavailability potential

ÖZ

Amaç: Mevcut çalışmanın amacı, QbD özellikli optimizasyon hazırlamak ve polimerler PLGA ve poloksamer-188 kullanılarak nano-prepikipitasyon ve ultrasonikasyon yöntemleri ile üretilen cinacalcet hidroklorürün dondurularak kurutulmuş polimerik nanopartiküllerinin oral biyoyararlanımını geliştirmekti.

Gereç ve Yöntemler: Formülasyonlar için taguchi ve Box-Behnken Tasarımları kullanılarak ilk tarama ve optimizasyon gerçekleștirildi. FT-IR ve DSC hiçbir etkileșim ortaya koydu ve seçilen ilaç ve polimerler arasında uyumsuzluk yoktu. Nanopartiküller \% ilaç salınımı, partikül boyutu analizi, zeta potansiyeli, PDI, SEM, TEM, P-XRD, TGA, DTA, in vitro ve in vivo ilaç salınım çalışması ile karakterize edildi.

Bulgular: In vitro ilaç salınım çalışması, ilacın difüzyon mekanizması ile optimize edilmiş partiden sürekli olarak salındı. Optimize edilmiş nanopartikül formülasyonu, deneysel modelin doğrulanması kullanılarak sayısal ve grafiksel yöntemlerle tanındı. Optimize edilmiş parti, parçacık boyutu, tuzak

*Correspondence: dave.ghose87@gmail.com, Phone: +91-9658961202/7008716377, ORCID-ID: orcid.org/0000-0001-9845-2758

Received: 19.08.2020, Accepted: 26.10.2020

๑Turk J Pharm Sci, Published by Galenos Publishing House. 
verimliliği ve in vitro ilaç salınımında fark edilen önemli bir değişiklik olmadan 6 ay boyunca ICH stabilite yönergelerine göre kararlıydı. Optimize edilmiş formülasyon için AUC ve Cmax verilerinin farmakokinetik parametreleri, saf ilaç süspansiyonu ile karşılaştırıldığında 3 ve 2,9 kat arttı.

Sonuç: Hazırlanan polimerik nanopartiküller formülasyonu, ön hiperparatiroidisi olan hastalarda uzun süreli normokalsemiyi yönetmek için model bir ilacın gelișmiş terapötik etkinliği ve biyoyararlanım potansiyeli için alternatif bir doğum sistemidir.

Anahtar kelimeler: PLGA, polimerik nanopartiküller, Taguchi, P-XRD, optimizasyon, biyoyararlanım potansiyeli

\section{INTRODUCTION}

Nanodrug delivery systems in medicine have evolved as a dependable and reliable technological boon as site-specific drug targeting in nanodrug development in the previous two decades., ${ }^{1,2}$ Polymeric-based nanoparticles are colloidal nature systems measuring around 10-100 nm. The experimental findings achieved are mostly within proximity of 100-500 $\mathrm{nm}$. The polymeric-based nanoparticulate systems have been considered an area of extensive research in novel drug delivery systems because of their all-encompassing biocompatibility and ease of altering properties. ${ }^{3}$

Numerous scientists worldwide have discovered abundant approaches, such as nanoprecipitation, solvent evaporation, salting out, emulsification-diffusion, and supercritical fluid technology. ${ }^{4}$ The polymeric nanoparticulate (PN) systems offer high applicability as an active delivery system. These PN versions comprehensively avail the drug near the intended site with augmented therapeutic activity and minimal adverse effects. ${ }^{5}$ These biopolymeric systems offer pivotal effectiveness with diminished toxicity and a potentiated therapeutic index.,

The polymeric micelle systems offer supplementary properties for safe and effective drug targeting at the tissue site, consistent biocompatibility, and potentiated stability during effective drug release. ${ }^{8-10}$ The current methodology of the drug cinacalcet hydrochloride $(\mathrm{CIH})$ encompasses the investigations streamlined to enhance the adequate oral bioavailability by nanoprecipitation-sonication techniques.11-15 These findings may lead to achieve enhanced stability, effective dissolution rate, and less toxicity. ${ }^{16}$ Nowadays, a heavy focus of attention has evolved in applying such materials for drug delivery implementation. These polymeric micelles are usually biodegradable and biocompatible hydrophobic polymer blocks, such as PCL, PLA, PEG, etc.17,18 From the varied range of biopolymers, poly-lactic-co-glycolic acid (PLGA) is considered an efficient and suitable class of copolymers that can be utilized for different Food and Drug Administrationapproved therapeutic devices. ${ }^{19-23}$

$\mathrm{ClH}$, a modern-day, first-line, well-known calcimimetic drug, is indicated for the safer management of tertiary hyperparathyroidism in people with chronic renal disorder, dialysis, and hypercalcemia in patients with parathyroid carcinoma. ${ }^{24,25}$ The oral form of $\mathrm{ClH}$ is considered the frontline medication in the generation of agents (i.e., the calcimimetics), with an innovative mechanism of action with absolute bioavailability of $20-25 \%$ and a log $p$ value of $6.8 .{ }^{26,27}$

The overall productiveness of the concept of $\mathrm{QbD}$ in optimizing the appropriate experimental design space is boosting vast acceptance in the development of pharmaceuticals. ${ }^{28,29}$ Box-
Behnken Design (BBD) optimization is a notable response surface method, which is predictable in determining the specific interactions of the parameters opted in optimization. ${ }^{30-32}$

Few research findings on freeze-dried $\mathrm{PNs}$ of $\mathrm{ClH}$, prepared by the nanoprecipitation with the ultrasonication method, except for few commercially marketed tablets of the strength of 30,60 , and $90 \mathrm{mg}$, are available in the literature. An alternative system of drug delivery can be developed for an enhanced therapeutic efficacy and bioavailability potential of $\mathrm{CIH}$.

\section{MATERIALS AND METHODS}

\section{Materials}

$\mathrm{CIH}$ was obtained as a gift sample from Cadila Healthcare Pvt. Ltd., Mumbai, India. PLGA was obtained as a gift sample from Dr. Reddy's lab, Hyderabad, India. Poloxamer-188 was received from Himedia, Mumbai, India. Mannitol was obtained from Himedia Chemicals Pvt. Ltd., Mumbai, India. Further, the necessary reagents, chemicals, and solvents used in this study were of analytical grade and utmost quality. The most authentic ARRIVE guidelines recommended that all animal studies or experiments be conducted in an alliance including Scientific Procedures Act, 1986 in the UK and insisted on allied, EU Directive 2010/63/EU guidelines for experiments on animals were authorized by the Animal Care Committee, RIPS, Berhampur, Institutional Animals Ethics (926/PO/Re/5/06/ CPCSEA, approval no: 87).

\section{Methods}

\section{Target product profile (TPP)}

TPP was predefined for the PN drug delivery system formulation of $\mathrm{ClH}$ to improve the oral bioavailability of the drug. The imperative principles of quality TTP (QTPP), such as the strength, administration route of the formulations, and their related pharmacokinetics-based process determining variables and factors, packaging stability attributes, drug release, and pharmacokinetic profiles of the drug. ${ }^{17,28}$

\section{Critical quality attributes (CQAs)}

Among the entire TPPs, several crucial and promising QAs are designated as CQAs on the basis of the criticality of effect upon patients' benefit. From the prepared polymeric formulations, CQAs such as time of stirring, mean particle size distribution, and zeta potential (ZP) were selected as per the TPPs., 17,27

\section{Screening of formulation excipients}

\section{Intrinsic solubility analysis}

Drug substance intrinsic solubility was estimated in various solvents, such as water, acetonitrile, phosphate buffer $\mathrm{pH}$ of 
6.8 and $7.4,0.1 \mathrm{~N} \mathrm{HCl}$, methanol, ethanol, dimethyl sulfoxide (DMSO), acetone, PEG200, PEG 400, and n-octanol. The drug's adequate capacity was included in each solvent and set aside on a mechanical shaker (Rivotek, Rivieria Glass Pvt. Ltd., Mumbai, India) along with a water bath regulated at $37 \pm 0.5^{\circ} \mathrm{C}$ for $72 \mathrm{~h}$. The vials were subsequently observed from distinct intervals for absolute solubilization of the drug substance, and afterward, the drug was further included if essential. All notable excipients were permitted to move into the centrifuged tubes (Spinwin MC02, TarsonsPvt Ltd.) Kolkata, India). The distinct quantity of the solubilized drug was detected and analyzed by ultravioletvisible (UV-vis) spectroscopy (UV-vis spectrophotometer, Labindia Ltd., Mumbai, India) for isolation of the undissolved or immiscible drug at a wavelength-maximum of $279 \mathrm{~nm}$ (i.e., $\lambda$ max of the drug) from the supernatant fraction. ${ }^{20}$

Development of analytical method by ultrafast liquid chromatography (UFLC)

A simple, rapid reverse phase RP-UFLC method was used for the quantification of $\mathrm{CIH}$. Drug separation was performed on a $250 \times 4.6 \mathrm{~mm}$ ID, ODS $\mathrm{C}_{18}$ column. The mixture of $(50: 50, \% \mathrm{v} / \mathrm{v})$ acetonitrile:phosphate buffer i.e., TBHS solution of $25 \mathrm{~mL}$ as a mobile phase and filtered through a $0.45 \mu \mathrm{m}$ millipore filter at a flow rate of $0.5 \mathrm{~mL} / \mathrm{min}$. Chromatographic detection was performed at a $\lambda$ max of $223 \mathrm{~nm}$, and an analytical column was maintained at a constant temperature $\left(25 \pm 1^{\circ} \mathrm{C}\right) .^{33}$

\section{Identification of QTPPs and CQAs in product development}

The QTPPs and CQAs are the major QbD elements to achieve product development and objectives for $\mathrm{ClH}$ nanoparticles, and the QTPP elements were set up based on drug sustained release, ZP, poly dispersibility index, and particle size. The QTPPs and CQAs parameters are depicted in Table 1.

Preliminary screening of influential factors using Taguchi design

The fundamental screening was attempted by exercising a combination of the 7-factors 2-levels Taguchi design to establish the significant vital factor(s) affecting the CQAs. For the Taguchi design, a combination of eight formulations was suggested and prepared.

\section{Preparation of PN formulation}

The development of PNs was attempted by adopting nanoprecipitation, followed by the ultrasonication method. The required quantity of PLGA was dissolved in the organic phase (acetone) at $50^{\circ} \mathrm{C}$ and added to the acetone solution of drug $\mathrm{ClH}$. The organic phase was included drop-wise into the additive (stabilizer) solution of poloxamer-188 (aqueous phase) with the glass syringe outfitted with a needle (gauge size, 26) at $3 \mathrm{~mL} /$ min and a stirring speed of $5000-15000 \mathrm{rpm}$ at $25^{\circ} \mathrm{C}$ (sample homogenizer T18 DIGITAL IKA RV, Germany). The ultrasound state parameter was set to $3 \mathrm{~s}$ with an interval of $2 \mathrm{~s}$ at $40 \mathrm{~W}$ for $5 \mathrm{~min}$. The residual amount of acetone was evaporated at $40^{\circ} \mathrm{C}$ beneath condensed pressure, using a Rotary evaporator (IKA RV 10 digital, Germany) for 2 min. The obtained nanosuspension was centrifuged (RC 4815F, Eltek India) at 9000 rpm for $30 \mathrm{~min}$ and lyophilized for $36 \mathrm{~h}$ at $-54^{\circ} \mathrm{C}$.

\section{Systematic formulation optimization studies}

The BBD response surface design with 3-factors and 3-levels of mixture components was taken into account for optimizing the PN formulations. Design expert ver. 12.1.1 software (StatEase, Minneapolis, MN, USA) was used for generating the experimental trials, where the ratio of Drug:PLGA (mg) (X1), poloxamer-188 concentration \% w/v (X2), and stirring speed (X3) was utilized as the independent variables or factors and with 3 -levels $(-1,0$, and 1$)$ was built to estimate the significant effect of these assorted variables or responses, namely cumulative \% drug release QT24\% (Y1), particle size in $\mathrm{nm}$ (Y2), ZP in $\mathrm{mV}$ (Y3), and polydispersity index (Y4). A sum of 17 trial formulations was organized together with five consecutive cumulative replicates of the center point trial, and further CQAs were formulated for evaluation.

\section{Lyophilization of optimized PNs}

Extensive research has proven that the samples obtained by lyophilization exhibit a porous structure with increased redispersibility and long-term steadiness. ${ }^{34}$ The lyophilized process was performed by using lyophilizer using ALPHA 1- 2 LO Plus CHRIST in order to produce the powdered freeze-dried state at a pressurized vacuum of $0.01 \mathrm{KPa}$ for about $48 \mathrm{~h}$ at $-50^{\circ} \mathrm{C}$ to obtain a drug loaded lyophilized PNs in case of run

Table 1. Quality target product profile and critical quality attributes for developing polymeric nanoparticles of cinacalcet hydrochloride

\begin{tabular}{|c|c|c|c|c|}
\hline QTTPs & Target & CQAs & Pre-determined target & Justification \\
\hline Dosage type & $\begin{array}{l}\text { Extended-release } \\
\text { dosage forms }\end{array}$ & $\begin{array}{l}\text { Cumulative drug } \\
\text { release at } 24 \mathrm{~h} \\
\text { (QT24\%) }\end{array}$ & $75-85 \%$ & $\begin{array}{l}\text { Sustained release of drug is the objective of the } \\
\text { study and is important for better absorption }\end{array}$ \\
\hline Dosage form & $\begin{array}{l}\text { Polymeric } \\
\text { nanoparticles }\end{array}$ & Zeta potential & $\geq \pm 20 \mathrm{mV}$ & $\begin{array}{l}\text { Highly critical factor as per the stability } \\
\text { perspective of the nano suspensions }\end{array}$ \\
\hline Dispersity & High dispersity & PDI & $0-0.4$ & $\begin{array}{l}\text { Uniformity in the particle distribution by size is } \\
\text { essential for therapeutic activity and, hence, is } \\
\text { highly critical }\end{array}$ \\
\hline
\end{tabular}

QTTPs: Quality target product profiles, CQAs: Critical quality attributes, $C_{\text {max }}$ : Maximum plasma concentration, AUC: Area under curve, PDI: Polydispersity index 
no: 16. The selected optimized formulation was further freezedried to the powder form by applying a suitable cryoprotectant (i.e., mannitol (2\%) and then subjected to micrometric characterization.

\section{Characterization of freeze-dried PNs}

\section{Fourier-transform infrared spectroscopy (FT-IR)}

The FT-IR spectroscopy was performed effectively for estimating the possible physical interactions of drug $\mathrm{CIH}$. FT-IR spectra of selected $\mathrm{ClH}$ and physical mixture (PM) with PLGA and poloxamer-188 were recorded on IR using $\mathrm{KBr}$ around the 4 $\mathrm{cm}^{-1}$ resolution. The compatibility studies of the drug-excipients were undertaken by computing the range of transmittance from 4000 to $400 \mathrm{~cm}^{-1}$. Peak matching was done to identify and determine any significant interactions among the other additives with $\mathrm{ClH}{ }^{35}$

\section{Differential scanning calorimetry (DSC)}

DSC studies were done to assess the interaction between the drug and the polymer. All the required samples $(10 \mathrm{mg})$ were subjected to heat in aluminum pans through effluent gas containing dry nitrogen. The DSC thermograms of pure drug of $\mathrm{ClH}$, excipients, and their respective $\mathrm{PMs}$ with $\mathrm{ClH}$ were determined. ${ }^{36}$

\section{Entrapment efficiency (EE)}

The percentage EE of $\mathrm{ClH}$ in the formulated or prepared PNs was anticipated directly by collecting the $\mathrm{ClH}$ content in the PNs. Samples of $10 \mathrm{~mL}$ of $\mathrm{ClH}$ PNs were allowed to centrifuge at $9000 \mathrm{rpm}$ for $30 \mathrm{~min}$ at $-4^{\circ} \mathrm{C}$ using a cooling centrifuge. The unencapsulated free drug can be removed using centrifugation dialysis. ${ }^{37}$ The supernatant free drug was calculated and validated, employing the UV-spectrophotometric method at wavelength $279 \mathrm{~nm}$. The drug EE (DEE) or (DEE \%) of nanoparticles was determined and calculated as indicated below by equation (1).

\% Entrapment Efficiency=(Total amount of drug-Free Drug)/ (Amount of total drug content) $\times 100 \ldots . . .(E q .1)$

\section{Particle size and ZP measurement}

Particle size, polydispersity index, and ZP were effectively determined by Photon Correlation Spectroscopy using the Zetasizer Nano-ZS Make-Malvern instrument. ZP implies that its value can be associated with the steadiness of colloidal dispersions. A high ZP will present the immovability or steadiness intended for molecules and particles that are small enough. ${ }^{38}$

\section{In vitro diffusion studies}

In this in vitro drug release study, the dialysis bag diffusion technique was implemented for pure-drug $\mathrm{ClH}$. Formulations ( $5 \mathrm{~mL}$ ) were placed in the dialysis bag, hermetically sealed, and dropped into $150 \mathrm{~mL}$ of $0.1 \mathrm{~N} \mathrm{HCl}$ under sink conditions for the first $2 \mathrm{~h}$. Then it was transferred into phosphate buffer solution of $\mathrm{pH} 6.8$ for $24 \mathrm{~h}$. The whole system was kept at $37^{\circ} \mathrm{C}$ with continuous magnetic stirring at $200 \mathrm{rpm}$. A sample $(2 \mathrm{~mL})$ was used by pipetting it from the compartment of the receptor at prefixed time intervals and replaced by a fresh and accurate quantity of $0.1 \mathrm{~N} \mathrm{HCl}$ and phosphate buffer of $\mathrm{pH}$ 6.8. Then, this 1 $\mathrm{mL}$ sample was taken, and $1 \mathrm{~mL}$ of ethyl acetate was added. The sample was vortexed in a cyclomixer, and $0.5 \mathrm{~mL}$ of this solution's supernatant layer was made in a test tube, kept for drying, and the mobile phase was added to this test tube and analyzed under RP-UFLC. ${ }^{38-41}$ Using a non-Fickian diffusion mechanism, kinetic studies were analyzed, allied with a concentration gradient, diffusion mechanics, and the extent of swelling. 42,43

\section{Solid-state characterization}

\section{Powder X-ray diffraction ( $P-X R D)$}

P-XRD (Rigaku, Japan, Smart Lab 9 kW) was implemented for diffraction studies. P-XRD studies were performed on the samples by exposure to nickel-filtered CuKa radiation ( $40 \mathrm{kV}$, $30 \mathrm{~mA}$ ) and allowed for the scan. Samples required for P-XRD related investigation were pure drug and optimized lyophilized PNs of $\mathrm{ClH}$. The results were then recorded as peak height (intensity) versus time (h).

\section{Scanning electron microscopy (SEM)}

SEM studies the texture or exact appearance of nanoparticles. A high resolution SEM (Jeol, Japan, JSM-6390LV) at $30 \mathrm{kV}$ was used. The formulation bearing to be tested sticks to the metallic stub, which is carbon-coated. SEM is useful for a detailed study of surface morphology. A high-energy electron helps to scan across the surface of a specimen, having an $\mathrm{Au}$ and $\mathrm{Pt}$ coating, which assists in improving contrast and the signal-tonoise ratio. ${ }^{44}$ The pure drug and optimized lyophilized PNs of $\mathrm{CIH}$ were studied and appropriately examined for determining surface morphology.

\section{Transmission electron microscopy (TEM)}

The exterior appearance or outline of the PNs was determined by TEM (100s, JEOL Ltd, Japan) and the PNs of $\mathrm{ClH}$, which was lyophilized and diluted with $2 \mathrm{~mL}$ of distilled water and consistently mixed by ultrasonication for $3 \mathrm{~min}$. The samples were arranged by inserting a drop of $\mathrm{PNs}$ of $\mathrm{ClH}$ upon a coated copper grid and air-dried. ${ }^{45}$

\section{Thermogravimetric analysis (TGA)}

TGA studies were implemented to justify the moisture content associated with weight loss in isothermal or non-isothermal stability studies. TGA denotes a vital aspect to identify and measure the amount of moisture content in pharmaceutical preparations. $^{46}$ During the stages of preformulation investigations, it is considered as an accurate method for the distinctness of polymorphs from hydrates or identification of monohydrates from among other hydrates, which may not be possible by DSC alone..$^{34,47}$

\section{Differential thermal analysis (DTA)}

It is well understood that thermal analytical techniques are highly requisite to study the polymorphisms and predict drug stability, solvation, degradation, drug compatibility with excipients, and impurity studies. Moreover, as compared to all, DTA is a wellestablished thermal method intended for an improvement to the melting point determination. ${ }^{48}$ 


\section{In vivo pharmacokinetic study}

A single dosage bioavailability technique was intended in animals under an unfed state. The estimation of the oral bioavailability for the optimized $\mathrm{ClH}$ formulation with respect to an aqueous suspension of $\mathrm{ClH}$ pure drug was determined in rabbits. ${ }^{49}$ The male rabbits of a healthy breed were selected for the present investigation. Then $1 \mathrm{~mL}$ of blood was collected carefully from the ear vein of the animal as a blank sample. Then $6.3 \mathrm{mg}$ of pure drug dissolved in $12.6 \mathrm{~mL}$ of distilled water was given to the animal orally, and $2.6 \mathrm{~mL}$ of formulation was given to another animal. The blood sample from the ear vein of both rabbits was drawn periodically of $2 \mathrm{~h}$ interval at a range of time points $(0,2,4,6,12,18$, and $24 \mathrm{~h})$. The collected samples of blood were subjected to a centrifuge for $20 \mathrm{~min}$, at $5000 \mathrm{rpm}$, after $20 \mathrm{~min}$. The supernatant layer of serum was carefully collected with the aid of a micropipette. The bioanalysis of the collected samples was done by using the analytical UFLC technique. A collection of pharmacokinetic criteria like half-life (t1/2), maximum plasma concentration $\left(C_{\max }\right)$, elimination rate constant $(K)$, maximum time to attain peak plasma concentration $\left(T_{\max }\right)$, and area under the curve (AUC) were calculated. The Animal Care Committee permitted the pharmacokinetic study, RIPS, Berhampur, Institutional Animals Ethics (926/PO/Re/5/06/CPCSEA, approval no: 87). All the animal experimentation congregated in accordance with the guidelines of ARRIVE and performed in association with the UK Animals (Scientific Procedures) Act, 1986 and connected guidelines, EU Directive 2010/63/EU for animal experiments.

\section{Accelerated stability study}

The accelerated stability studies were performed as per the $\mathrm{ICH}$ guidelines of optimized nanoparticles filled with hard gelatin capsules dosages form was subjected to accelerated stability at temperature $40^{\circ} \mathrm{C}$ and $\mathrm{RH}$ of $75 \%$ (i.e., relative humidity) for a 6-month period applying stability chamber ( $\mathrm{TH}-$ 200G, Thermolab, Thane, India). The samples were removed carefully from stability at 0,1,2,3, and 6-month time intervals and subjected for evaluation of particle analysis, ZP, and drug release.

\section{RESULTS}

\section{Excipients selection on the basis of solubility studies}

$\mathrm{CIH}$ showed a mean saturation solubility in selected solvents of $3660 \mu \mathrm{g} / \mathrm{mL}, 3256 \mu \mathrm{g} / \mathrm{mL}$, and $2.471 \mu \mathrm{g} / \mathrm{mL}$ in acetone, DMSO, and ethanol. Among different solvents, acetone showed the highest quantitative solubility and, hence, was selected. Most negligible solubilities were observed in methanol $0.000345 \mu \mathrm{g} / \mathrm{mL}$.

\section{Taguchi screening design for identifying critical factors}

The preliminary screening (Taguchi OA design) was applied to filter out the most influential factors with several trials for each element; two levels opted for low and high ( 1 and 2 ). Table 2 shows the respective coded and actual values for the formulations based on the CQAs. The influence of multiple factors, like A-PLGA concentration, B-poloxamer-188 concentration, C-Stirring speed, D-Stirring time, E-Ultrasonication time,
F-Temperature, and G-Stirring type were studied. The $p$ values of the regression coefficients $\left(R^{2}\right)$ were determined to evaluate the relevance of each factor on each response. The model factors $A, B$, and $C$ are significant since the $p$ value is less than the standard $\alpha$ value (0.05), and other factors having $p$ values higher than 0.1000 indicate the model terms are not significant. Thus, from the factor screening study, the factors A-Drug:PLGA concentration, B-poloxamer-188 concentration, and C-Stirring speed were finally selected as influential factors for further optimization.

\section{Experimental design, optimization, and analysis}

By keeping the other factors constant at a low level, the concentrations of PLGA, poloxamer-188, and stirring speed were changed. On the basis of preliminary data from Paretochart analysis, three levels were selected (-1, 0, and 1) for each of the factors. Table 3 represents a total of 17 runs on applying a three-factor at three-level $3^{3}$ BBD. The characterization studies of each formulation were done to investigate the effect of different factors, like A-Drug:PLGA concentration, B-poloxamer-188 concentration, and C-Stirring speed on individual CQAs.

\section{Response surface analysis of $2 D$ and $3 D$ plot}

\section{Effect of the factor on CQA QT24\%}

Figure 1a, it portrays the 2D (contour) and 3D plots of the CQA QT24\%. Thorough understanding, it is anticipated that at a low level (-1) of Drug:PLGA concentration and high level (1) level of poloxamer-188 concentration, the red region is prevalent, more than $75 \%$ of drug release in $24 \mathrm{hr}$. run no: 16 has a maximum percentage of drug release, i.e., $76.945 \%$. In contrast, run no: 14 has a minimum QT24\% value, i.e., $29.411 \%$, due to the high level (1) of Drug:PLGA concentration. Increased polymer concentration increases the level of particle size distribution and aggregation, which retards the release behavior. The result suggests an optimum drug concentration: Polymer ratio is required for better dissolution of the drug. It can also be inferred that the concentration of stabilizer (poloxamer-188) has a noticeable impact on improved drug dissolution.

\section{Effect of the factor on CQA PS}

Figure $1 \mathrm{~b}$, portrays the $2 \mathrm{D}$ (contour) and $3 \mathrm{D}$ plot of the CQA PS. The particle size ranges from $147.898 \mathrm{~nm}$ for run 16 to $450.211 \mathrm{~nm}$ for run 8 . It has been noted that at low level $(-1)$ of factors A-Drug:PLGA concentration and high level (1) of B-poloxamer-188 concentration indicated by the blue zone, where the lower range of particle size is achieved..$^{50}$ It can be assumed that at the lower level of A-Drug:PLGA concentration efficiently assists in getting a reduction in the particle size, and this characteristic increases significantly concerning a higher level, depicted by the dark yellowish zone. An increase in the stirring rate also influences the particle size, i.e., size reduction. ${ }^{51}$

\section{Effect of the factor on CQA ZP}

Figure 1c, portrays the 2D (contour) and 3D plots of the CQA polydispersity index (PDI). Both A-Drug:PLGA concentration and 
B-poloxamer-188 concentration seem to influence the CQA ZP. It ranges from $-6.321 \mathrm{mV}$ for run $12-22.7 \mathrm{mV}$ for run 16 at a low level 0.5 of A-Drug:PLGA concentration and B-poloxamer-188 concentration at more than level 1 show higher value, which predicts to have a substantial impact on the CQA. ${ }^{52}$

\section{Effect of the factor on CQA PDI}

Figure 1d, portrays the contour plot and the 3D plot of the CQA PDI. Both A-DRUG: PLGA concentration and B-poloxamer-188 concentration seem to equally influence the PDI. It ranges from 0.12 to run 14 to 0.65 for run 8 . The results showed that, PDI's value remains below 0.2 only when both A-Drug:PLGA concentration and B-poloxamer-188 concentration have a value above the level 0.5. Uniform-size distribution is a vital requirement for getting drug absorbed at Gl membrane. The stabilizer system is responsible for maintaining uniform-size distribution.

\section{Analysis of variance (ANOVA) of BBD design}

The summary of ANOVA for different factors and their significance with respect to the quadratic model was determined. After conducting the design matrix, the resultant model F value for QT24\%, PS, ZP, and PDI is calculated as $21.76,11.80,5.06$, and 5.72 , respectively. $P$ values of the model for various CQAs was less than 0.05 ( $\alpha=0.05$ ), which justifies that the quadratic model is significant. The lack-offit $p$ values for QT24\%, PS, ZP, and PDI were calculated as $0.565,0.157,0.001$, and 0.455 . It is not significant, relative to pure error (i.e., $p$ value $>\alpha$ ), which is desirable for a fit model. For the CQA QT24\%, the model terms, such as A, B, and $C^{2}$ are significant. For the CQA PS, the model term $B$ is substantial. $A, A B, A^{2}$ are significant model terms regarding of $Z P$. In PDI as CQA, the model terms such as $B, A B$, and $B^{2}$ are significant. $P$ values less than 0.05 indicate the model terms are significant.

\section{DISCUSSION}

\section{Summary of $B B D$ quadratic model}

The BBD quadratic model summary in the optimization process is applied to optimize the PNs of $\mathrm{CIH}$. In CQA QT24\%, the predicted $R^{2}$ of 0.7627 is acceptable, with the adjusted $R^{2}$ of 0.9211 . The precision ratio of 17.021 estimates good signal-tonoise ratio. In PS's case, the predicted $R^{2}$ of 0.2844 is not close to the adjusted $R^{2}$ of 0.8586 because it may indicate a significant block effect, with the precision ratio of 12.012 indicating an adequate signal. For ZP, the predicted $\mathrm{R}^{2}$ of -1.0737 implies that the overall mean may be a better predictor with the adjusted $\mathrm{R}^{2}$

Table 2. Design matrix for factor screening as per Taguchi design along with the experimental results of various CQAs and factors with their respective low and high levels

\begin{tabular}{|c|c|c|c|c|c|c|c|c|c|c|c|}
\hline Runs & A & B & C & $D$ & $E$ & $\mathrm{~F}$ & $\mathrm{G}$ & QT24\% & $\begin{array}{l}\text { Particle } \\
\text { size }(\mathrm{nm})\end{array}$ & $\mathrm{ZP}(\mathrm{mV})$ & PDI \\
\hline 1 & 2 & 1 & 2 & 1 & 2 & 1 & 2 & 47.983 & 252.4 & -27.8 & 0.299 \\
\hline 2 & 2 & 2 & 1 & 1 & 2 & 2 & 1 & 67.342 & 181.0 & 22.32 & 0.175 \\
\hline 3 & 1 & 2 & 2 & 2 & 2 & 1 & 1 & 32.341 & 276.3 & -22.3 & 0.356 \\
\hline 4 & 2 & 2 & 1 & 2 & 1 & 1 & 2 & 72.903 & 191.5 & 18.231 & 0.127 \\
\hline 5 & 1 & 1 & 1 & 2 & 2 & 2 & 2 & 47.785 & 266.7 & -22.3 & 0.368 \\
\hline 6 & 2 & 1 & 2 & 2 & 1 & 2 & 1 & 70.234 & 224.1 & -17.312 & 0.221 \\
\hline 7 & 1 & 1 & 1 & 1 & 1 & 1 & 1 & 59.234 & 266.7 & -23.6 & 0.368 \\
\hline 8 & 1 & 2 & 2 & 1 & 1 & 2 & 2 & 63.456 & 286.7 & -29.1 & 0.653 \\
\hline Factors & Codes & & & & & & & \multicolumn{2}{|c|}{ Low level (-1) } & \multicolumn{2}{|c|}{ High level $(+1)$} \\
\hline $\begin{array}{l}\text { PLGA } \\
\text { concentration (mg) }\end{array}$ & $A$ & & & & & & & 20 & & 60 & \\
\hline
\end{tabular}

Poloxamer-188

concentration B

$0.5 \%$

$1.5 \%$

(gm\%)

\begin{tabular}{llll}
\hline $\begin{array}{l}\text { Stirring speed } \\
\text { (rpm) }\end{array}$ & C & 5000 & 10000 \\
\hline Stirring time (h) & D & 1 & 2 \\
\hline $\begin{array}{l}\text { Ultrasonication } \\
\text { time (min) }\end{array}$ & E & 5 & 10 \\
\hline Temperature ${ }^{\circ} \mathrm{C}$ & $\mathrm{F}$ & 25 & 40 \\
\hline Stirring type & G & Magnetic & Mechanical \\
\hline
\end{tabular}

CQAs: Critical quality attributes, PLGA: Poly-lactic-co-glycolic acid, PDI: Polydispersity index, ZP: Zeta potential 
of 0.6956 . For PDI, the predicted $\mathrm{R}^{2}$ of 0.0433 is not as close to the adjusted $R^{2}$ of 0.7264 , with a precision ratio of 7.696 , indicating an adequate signal.

\section{Analysis for identification of overlay plot and design space}

In the case of optimization, the preferable target was allotted for various responses regarding QT24\%, PS, ZP, and PDI as per the target identified in finding various QTPPs and CQAs. Based on the required quality target product profiles (QTTP), limits for different CQAs were set and processed for optimization. Run 16 was the optimized PNs of $\mathrm{ClH}$, where BBD achieved comprising $30 \mathrm{mg}$ of $\mathrm{ClH}$ : $30 \mathrm{mg}$ of PLGA, poloxamer-188 $(1.5 \%$ $\mathrm{w} / \mathrm{v}$ ) concentration, and stirring speed of $10000 \mathrm{rpm}$. Evaluation of the proposed optimized formulation showed QT24\% of $76.945 \%$, PS of $147.898 \mathrm{~nm}$, ZP of $22.7 \mathrm{mV}$, and PDI of 0.398 . The optimized PNs of $\mathrm{ClH}$ exhibited to achieve the QTTP in an optimum composition.

\section{Characterization of PNs}

FT-IR

$\mathrm{ClH}$-polymer interactions were assessed for $\mathrm{ClH}$ and physical $\mathrm{PM}$ with PLGA and poloxamer-188. The observations were recorded

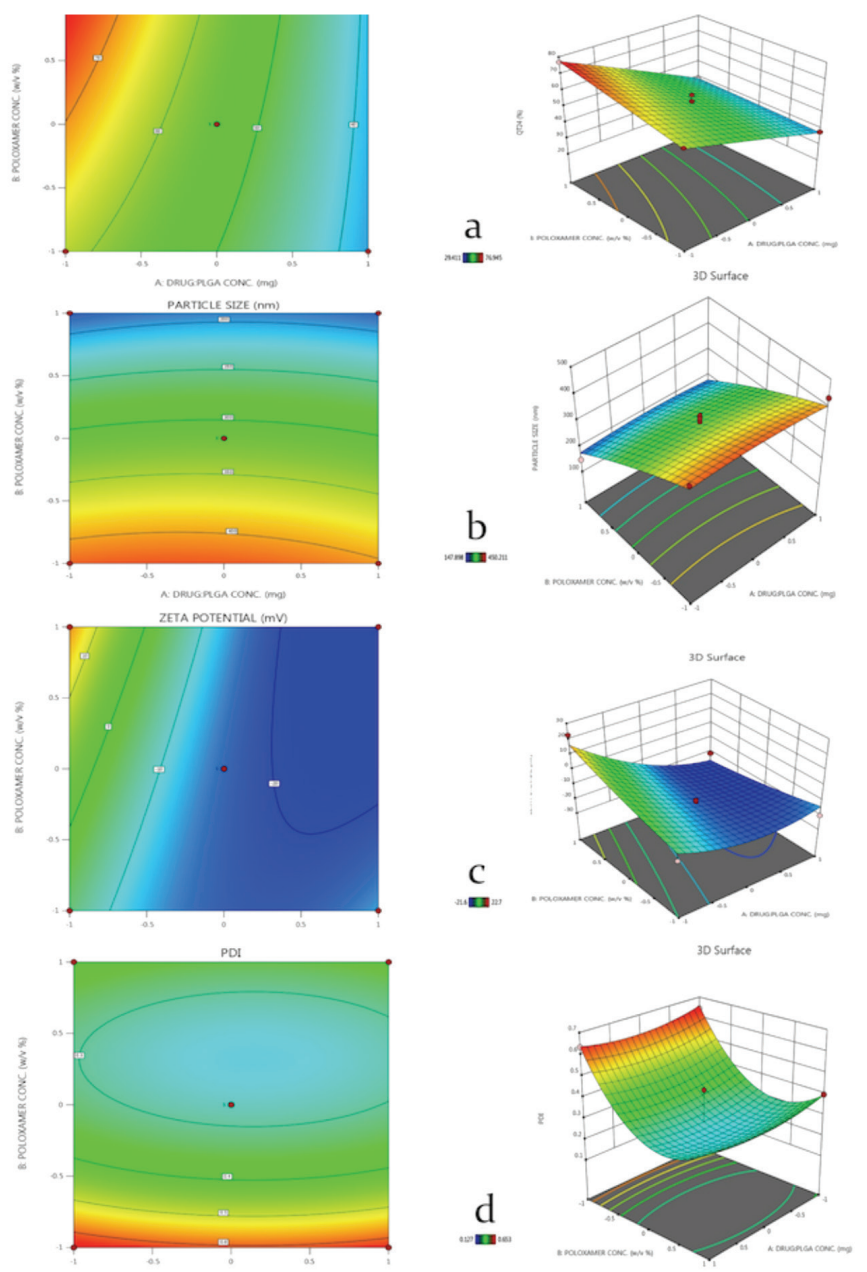

Figure 1. Contour plots (2D) and response surface plots (3D) of selected independent factors on selected dependant factors: QT24\% (a); particle size (b); zeta potential (c), and polydispersibility index (d) on IR using $\mathrm{KBr}$ with a resolution of $4 \mathrm{~cm}^{-1}$ over the region 4000 $400 \mathrm{~cm}^{-1}, \mathrm{FT}-\mathrm{IR}$ analysis for pure $\mathrm{ClH}$ exhibited absorption spectral bands as shown in Figure 2, at $1517 \mathrm{~cm}^{-1}$ designated to methyl (-CH3), $1338 \mathrm{~cm}^{-1}$ assigned to (-CH2), $2909 \mathrm{~cm}^{-1}$ selected to amide $(-\mathrm{NH}), 796 \mathrm{~cm}^{-1}$ fixed to the trifluoromethyl (-CF3), and absorption bands at $805 \mathrm{~cm}^{-1}$ assigned to be designated to benzene $\left(-\mathrm{C}_{6} \mathrm{H}_{6}\right)$. The corresponding peaks obtained for the PM from the spectral analysis showed no alterations. The outcome showed the compatibility between $\mathrm{ClH}$ and other excipients.

\section{DSC}

DSC curve of $\mathrm{CIH}$ exhibited an endothermic peak at a temperature of $181.9^{\circ} \mathrm{C}$, the onset temperature of $178.3^{\circ} \mathrm{C}$, and the end set temperature of $184.9^{\circ} \mathrm{C}$, matching its melting point. The DSC thermograms of $\mathrm{ClH}$ and $\mathrm{PMs}$ of $\mathrm{ClH}$ with excipients were observed. The thermogram of $\mathrm{ClH}$ showed an intense endothermic sharp peak at fusion temperature of $181.90^{\circ} \mathrm{C}$ with onset temperature at $178.33^{\circ} \mathrm{C}$, and latent heat of fusion was observed to be $-28.26 \mathrm{~mJ}$, predicted crystalline drug nature whereas that of PMs also depicted the same, as shown in Figure 3. Studies indicated no change in peak characteristics for pure drug and formulation; thus, no interactions between drug and excipients were inferred in the present study.

\section{Micromeritic studies}

Table 4 enlists micrometric properties of lyophilized PNs, where the angle of repose is $27.96 \pm 1.5$ degrees and \% moisture content is $2.8 \pm 0.4$, respectively. Based on these micrometric properties, Run-16 was selected to be the best formulation with better flow properties.

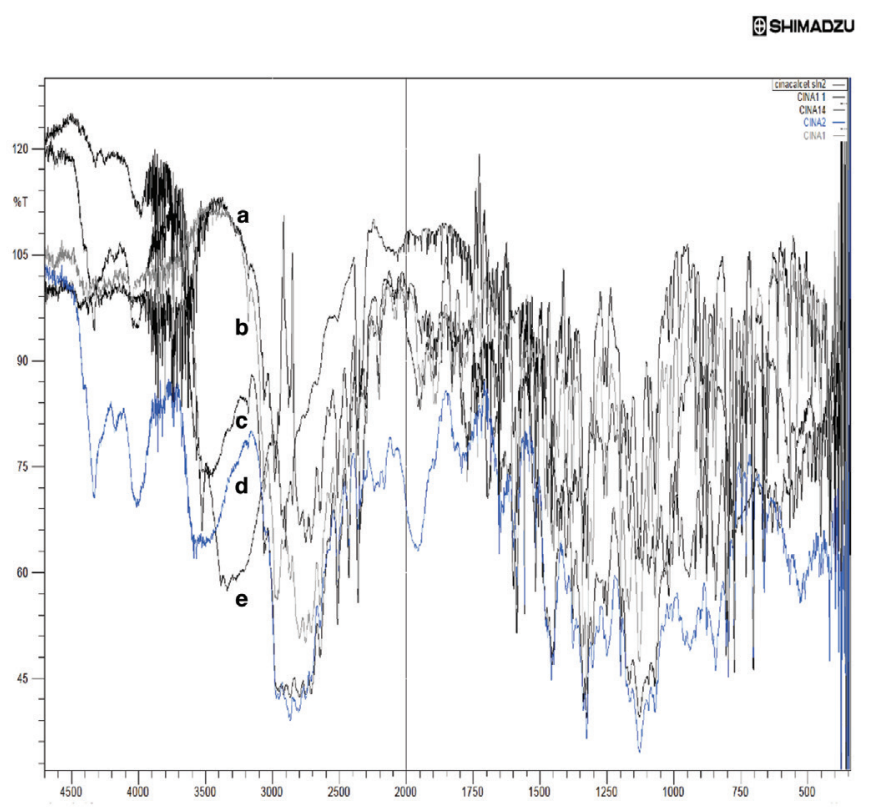

Figure 2. FT-IR spectra of pure drug (a); physical mixture of drug with PLGA polymer (b); physical mixture of drug with polaxomer-188 (c); polaxomer-188 (d) and, PLGA polymer (e)

FT-IR: Fourier-transform infrared spectroscopy, PLGA: Poly-lactic-co-glycolic acid 


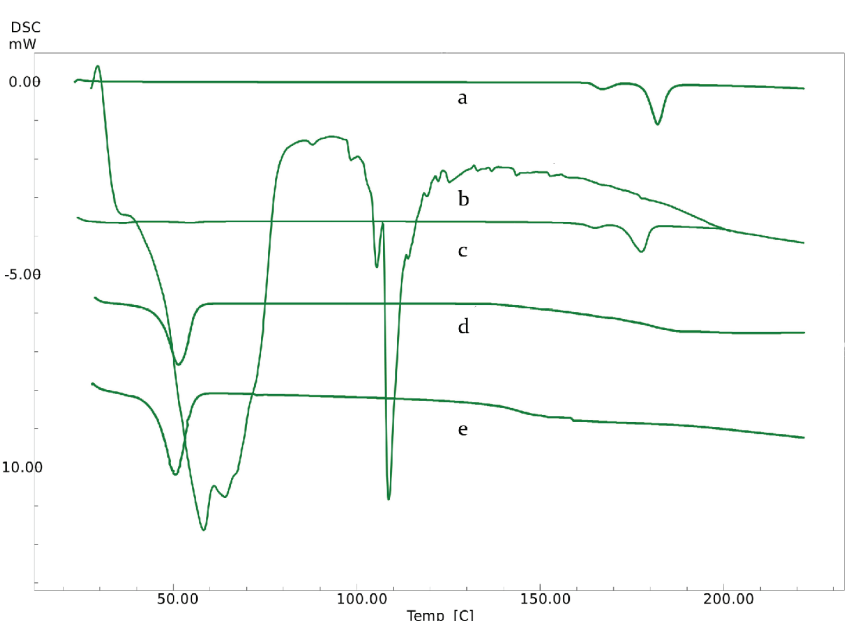

Figure 3. DSC thermogram of pure drug (a); PLGA polymer (b); drug with PLGA polymer (c); drug with polaxomer-188 (d), and polaxomer-188 (e) DSC: Differential scanning calorimetry, PLGA: Poly-lactic-co-glycolic acid
EE

Among all the trials Run-16 (i.e., Drug:PLGA concentration $30: 30 \mathrm{mg}$ ), poloxamer-188 1.5\% w/v at stirring speed of 10000 rpm was found to have higher EE (69.56\%).

\section{Particle size and ZP determination}

The zeta-sizer instrument analyzed the particle size of all formulations. The optimized size range for the $\mathrm{PNs}$ of $\mathrm{ClH}$ was 147.8 nm [i.e., for Run-16 (Figure 4a)]. The developed $\mathrm{CIH}$ loaded PLGA-NPs formulation showed spherical surface morphology and uniform particle size distribution of $<200 \mathrm{~nm}$. The increase in PLGA concentration had a potential behavior on the particle size, which produced a hazy appearance (i.e., due to the increased aggregation). The ZP results for the respective formulation were $22.7 \mathrm{mV}$ for Run-16. (Figure $4 \mathrm{~b}$ ).

$P-X R D$

The X-RD patterns of optimized $\mathrm{PNs}$ of $\mathrm{ClH}$ and pure-drug $\mathrm{ClH}$ are depicted in Figure 5a and Figure 5b. Pure-drug $\mathrm{ClH}$ showed

Table 3. Composition of various PNs of CIH as per BBD along with the obtained CQAs responses and their coded levels QT24\% cumulative $\%$ drug release at $24 \mathrm{~h}$

\begin{tabular}{|c|c|c|c|c|c|c|c|}
\hline \multirow[b]{2}{*}{ Runs } & \multirow{2}{*}{$\begin{array}{l}\text { Factor } 1 \\
\text { A:X1 PLGA:Drug } \\
\text { ratio (mg) }\end{array}$} & \multirow{2}{*}{$\begin{array}{l}\text { Factor } 2 \\
\text { B:X2 } \\
\text { polaxomer-188 } \\
\text { concentration }(\% \mathrm{w} / \mathrm{v})\end{array}$} & \multirow{2}{*}{$\begin{array}{l}\text { Factor } 3 \\
\text { C:X3 } \\
\text { stirring speed } \\
\text { (rpm) }\end{array}$} & \multirow{2}{*}{$\begin{array}{l}\text { Response Y1 } \\
\text { QT24\% }\end{array}$} & \multirow{2}{*}{$\begin{array}{l}\text { Response Y2 } \\
\text { Particle size } \\
\text { (nm) }\end{array}$} & \multirow{2}{*}{$\begin{array}{l}\text { Response Y3 } \\
\text { Zeta potential } \\
(\mathrm{mV})\end{array}$} & \multirow{2}{*}{$\begin{array}{l}\text { Response Y4 } \\
\text { PDI }\end{array}$} \\
\hline & & & & & & & \\
\hline 1 & -1 & 0 & -1 & 60.345 & 390.311 & 13.23 & 0.453 \\
\hline 2 & 1 & 0 & -1 & 35.692 & 348.781 & -21.21 & 0.432 \\
\hline 5 & -1 & -1 & 0 & 62.542 & 432.367 & -10.324 & 0.642 \\
\hline 6 & 0 & 1 & 1 & 60.321 & 232.345 & -18.674 & 0.299 \\
\hline 7 & 0 & 1 & -1 & 45.432 & 236.544 & -19.421 & 0.349 \\
\hline 11 & 0 & 0 & 0 & 55.342 & 293.245 & -16.322 & 0.231 \\
\hline 12 & -1 & 0 & 1 & 67.311 & 290.312 & -6.321 & 0.171 \\
\hline 13 & 1 & -1 & 0 & 37.985 & 432.211 & -20.3 & 0.634 \\
\hline 14 & 1 & 0 & 1 & 29.411 & 286.768 & -21.24 & 0.127 \\
\hline 15 & 0 & 0 & 0 & 59.093 & 290.578 & -18.431 & 0.231 \\
\hline 16 & -1 & 1 & 0 & 76.945 & 147.898 & 22.7 & 0.398 \\
\hline 17 & 0 & -1 & 1 & 44.252 & 403.231 & -12.234 & 0.543 \\
\hline \multicolumn{4}{|c|}{ Independent variables } & \multicolumn{4}{|l|}{ Levels } \\
\hline
\end{tabular}

PNs: Polymeric nanoparticles, CIH: Cinacalcet hydrochloride, BBD: Box-Behnken Design, CQAs: Critical quality attributes, PDI: Polydispersity index, PLGA: Polylactic-co-glycolic acid 
sharp peaks at the diffraction angles, such as $11.9^{\circ}, 15.3^{\circ}, 16.9^{\circ}$, $19.3^{\circ}, 22.4^{\circ}, 23.6^{\circ}$, and $25.2^{\circ}$, indicating a typical crystalline pattern. Optimized PNs of $\mathrm{ClH}$ showed a reduction (i.e., the minimal peak intensity at those angles), indicating amorphous form and confinement of the drug at the molecular level in the freeze-dried form.

\section{SEM and TEM}

Figure $6 \mathrm{a}$ and Figure 6b illustrate the scanning electron microscopic pictures of pure-drug $\mathrm{ClH}$ and optimized PNs of $\mathrm{CIH}$. The SEM of pure-drug $\mathrm{CIH}$ appears to be a rough surface
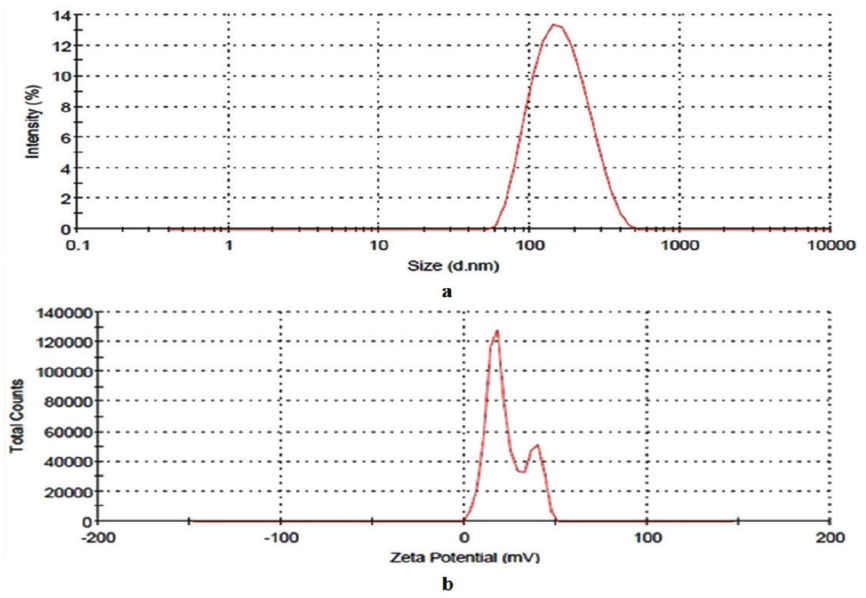

Figure 4. Particle size distribution and zeta potential curves of optimized formulation batch
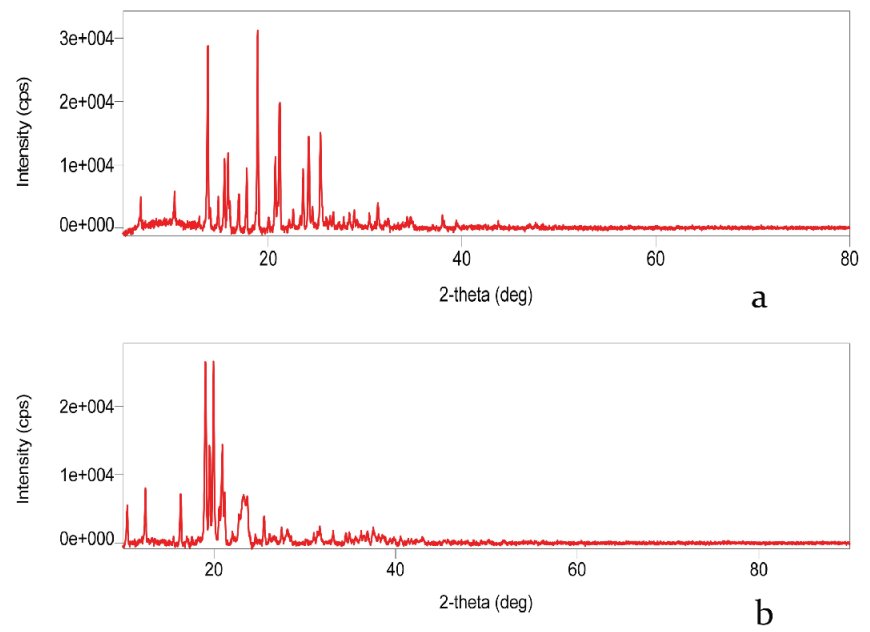

Figure 5. X-RD curves of pure drug (a) and optimized formulation batch (b) $\mathrm{X}-\mathrm{RD}$ : X-ray diffraction with crystalline structures. However, the TEM studies of the optimized PNs of $\mathrm{ClH}$ predict the amorphous structure with spherical smooth-surfaced particles (Figure 7).

\section{TGA}

The TGA curve of pure-drug $\mathrm{ClH}$ exhibits that at an initial temperature of $23^{\circ} \mathrm{C}$, the weight loss is found to be $0.045 \mathrm{mg}$, with $\%$ weight loss of 2.76 , which observed a straight line up to a temperature of $280^{\circ} \mathrm{C}$ with $1.42 \mathrm{mg}$ with $\%$ weight loss of 93.42. The TGA curve of optimized PNs of $\mathrm{ClH}$ exhibited at $24^{\circ} \mathrm{C}$ temperature, weight loss was found to be $0.24 \mathrm{mg}(\%$ weight loss of 8.22 ), followed by a sharp decrease of curve observed at $180^{\circ} \mathrm{C}$ with weight loss of $1.70 \mathrm{mg}(57.58 \%)$, as depicted in Figure $8 \mathrm{a}$ and $8 \mathrm{~b}$, and its decline up to $480^{\circ} \mathrm{C}$; however, later on, it showed a straight line up to $800^{\circ} \mathrm{C}$. This curve indicates that the optimized formulation seems to be significant and thermo-stable concerning \% weight loss compared to $\mathrm{ClH}$ 's pure drug.

\section{a}

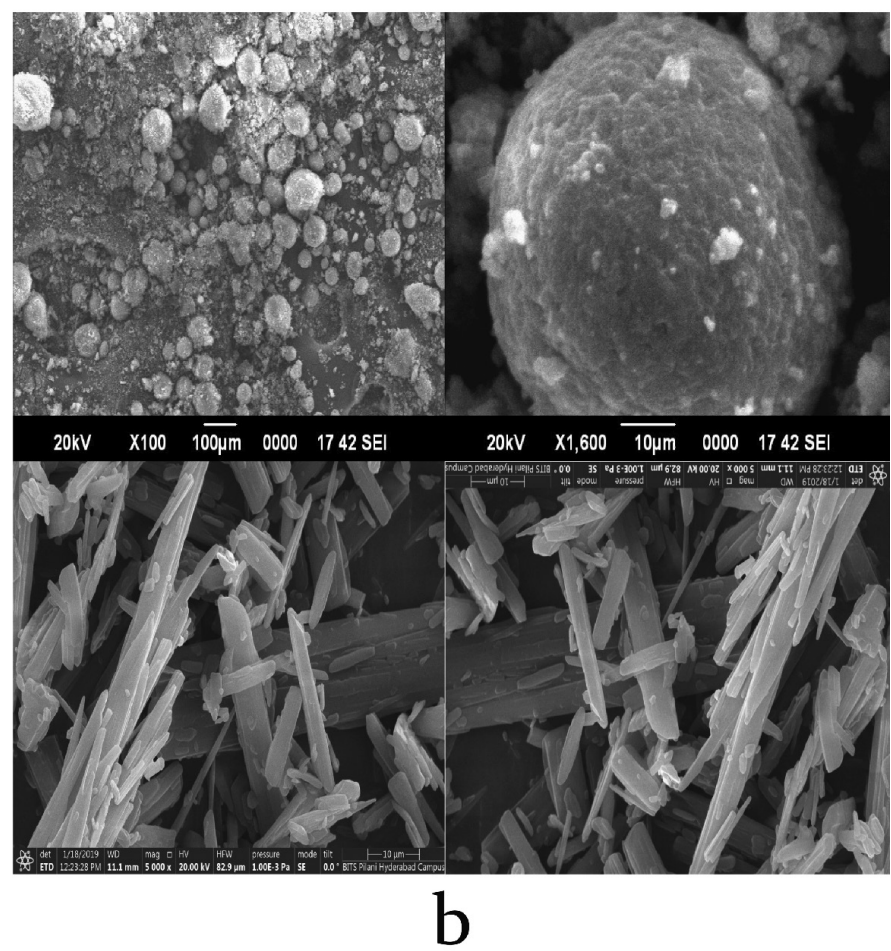

Figure 6. SEM images of optimized formulation batch (a) and pure drug (b) SEM: Scanning electron microscopy

Table 4. Carr's index, angle of repose, moisture content, and in vivo pharmacokinetic parameters of pure drug and optimized formulation batch

\begin{tabular}{lllllllll} 
Formulations & Carr's index & $\begin{array}{l}\text { Angle of } \\
\text { repose }(\theta)\end{array}$ & $\begin{array}{l}\text { Moisture } \\
\text { content }(\%)\end{array}$ & $C_{\text {max }}(\mu \mathrm{g} / \mathrm{mL})$ & $\begin{array}{l}\mathrm{T}_{\max } \\
(\mathrm{h})\end{array}$ & $\mathrm{K}_{\mathrm{e}}$ & $\begin{array}{l}\mathrm{AUC} \boldsymbol{C}^{\infty} 0 \\
(\mu \mathrm{g} / \mathrm{h}) / \mathrm{mL}\end{array}$ & $\mathrm{t}_{1 / 2}$ \\
\hline Pure drug $(\mathrm{ClH})$ & $16.66 \pm 1.08$ & $35.5 \pm 1.98$ & $3.2 \pm 0.31$ & 0.671 & 4 & 190.773 & 10.457 & 0.0036 \\
\hline $\begin{array}{l}\text { Optimized } \\
\text { formulation }\end{array}$ & $12.20 \pm 0.98$ & $27.96 \pm 1.5$ & $2.8 \pm 0.4$ & 1.945 & 6 & 192.737 & 31.558 & 0.0035 \\
\hline
\end{tabular}


DTA

The DTA curve of $\mathrm{CIH}$ exhibited melting point at $181^{\circ} \mathrm{C}$, a significant decrease in intensity of peak, which signifies an endothermic reaction with respect to the change in the melting point. Similarly, in the case of optimized PNs showed melting

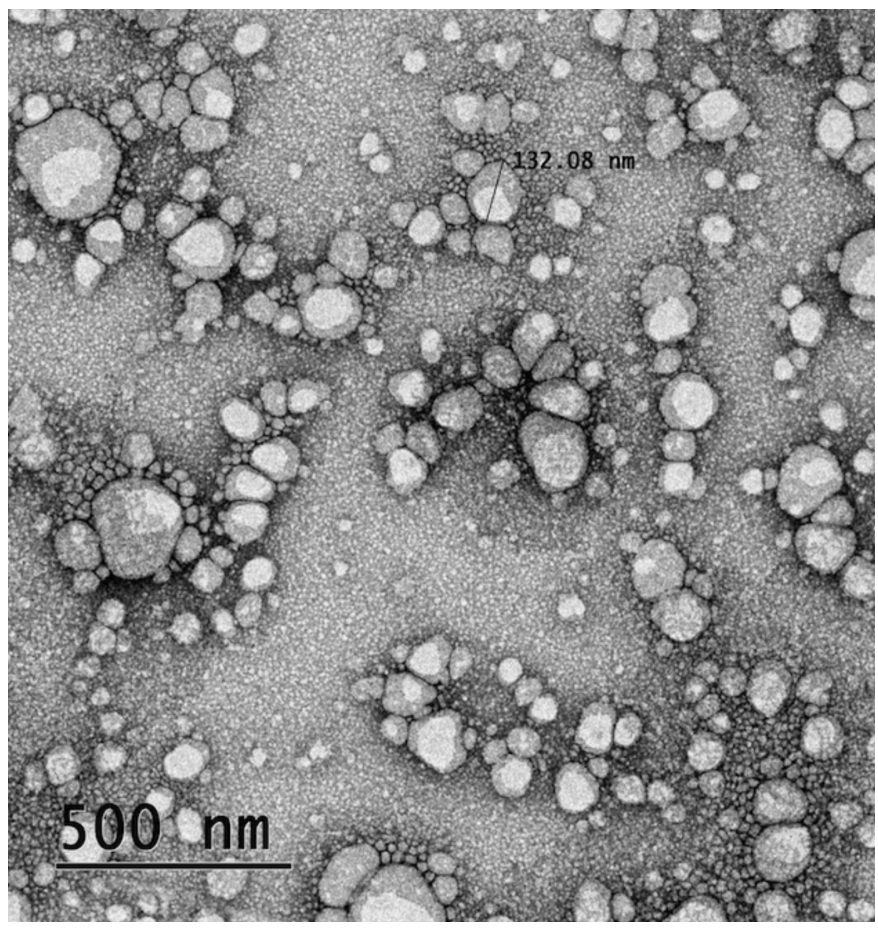

Figure 7. TEM image of optimized formulation batch TEM: Transmission electron microscopy
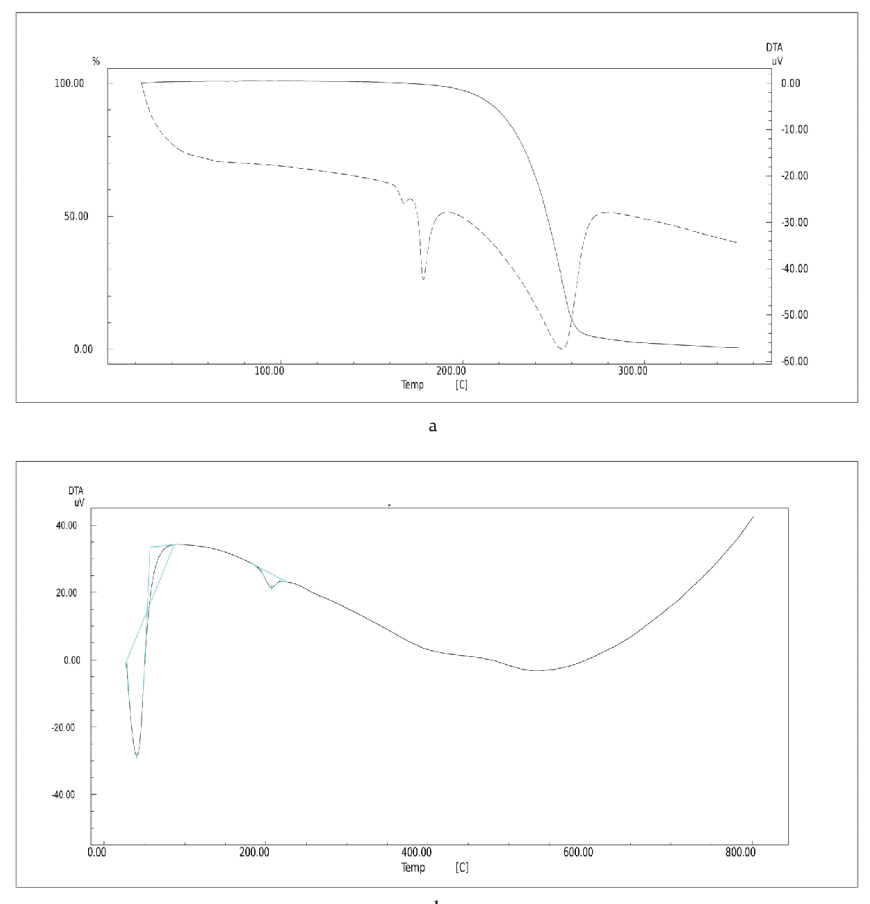

Figure 8. TGA plot of pure drug (a) and optimized formulation batch (b) TGA: Thermogravimetric analysis point at $226^{\circ} \mathrm{C}$, that means sharp change in peak of curvature in case of optimized batch due to the change in melting point at enthalpy of $348.6 \mathrm{~mJ}$. Finally the onset of peaks for the optimized batch showed at $21^{\circ} \mathrm{C}$ and $67.31^{\circ} \mathrm{C}$ with the endset enthalpy at 67.31 and $13.5 \mathrm{~J}$ respectively. The details of DTA thermograms of optimized PNs formulations and its pure drug of $\mathrm{ClH}$ are depicted in Figure 9a and 9b.

\section{In vitro diffusion studies}

The behavior pattern of drug release for the optimized PNs of $\mathrm{CIH}$ and pure-drug of $\mathrm{CIH}$ is illustrated in Figure 10. The pattern of drug release was observed from the in vitro diffusion studies for the optimized drug loaded PNs and pure drug as shown in Figure 10. The graph indicated the optimized batch showed a substantial improvement drug release or nearly two times drug release than compared to pure drug after performing 6 h study. Hence, an optimum combination of Drug:PLGA and poloxamer-188 provides a better dissolution profile than the pure drug. For the better understanding about the drug release mechanism and fitting kinetic models, different kinetic model equations are applied such as zero-order, first order and Higuich models respectively. After applying such models, the $\mathrm{R}^{2}$ values for each kinetic model were calculated separately for pure drug as well as for drug loaded PNs. The obtained $R^{2}$ values for pure drug, 0.921 in case of zero-order, 0.934 for first-order and 0.940 Higuchi model, and similarly the optimized drug loaded PNs $R^{2}$ values was found to be $0.835,0.868$, and 0.944 , respectively. The $\mathrm{R}^{2}$ obtained for different kinetic models suggested that Higuchi model for pure-drug $\mathrm{ClH}$ and optimized PNs of $\mathrm{ClH}$ were highest fit. The value of release exponent (n) for the pure-drug $\mathrm{CH}$ and optimized $\mathrm{PNs}$ of $\mathrm{ClH}$ formulation

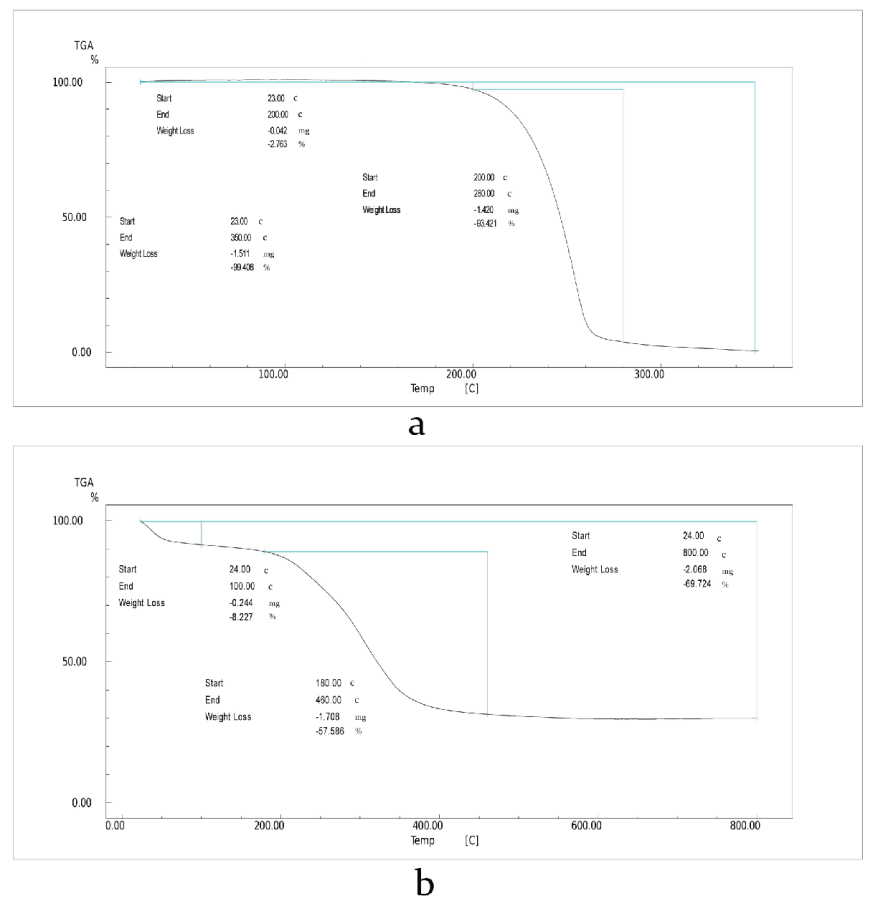

Figure 9. DTA plot of pure drug (a) and optimized formulation batch (b) DTA: Differential thermal analysis 
was 0.689 and 0.478 . Hence, the drug release from pure drug follows Fickian diffusion kinetics, whereas optimized PNs of $\mathrm{ClH}$ follow non-Fickian diffusion kinetics.

\section{In vivo pharmacokinetic study}

From the in vivo pharmacokinetic study data table (Table 4) and mean plasma concentrations vs. the time curve (Figure 11) showed that $T_{\max }$ was achieved at $6 \mathrm{~h}$ in case of optimized $\mathrm{PNs}$ and at $4 \mathrm{~h}$ in case of pure drug, which indicated sustained release time of the drug. $\mathrm{C}_{\max }$ of optimized $\mathrm{PNs}$ of $\mathrm{ClH}$ was $1.945 \mathrm{mcg} / \mathrm{mL}$, whereas compared to the pure drug of $\mathrm{ClH}$, it is $0.671 \mu \mathrm{g} / \mathrm{mL}$. AUC of optimized PNs of $\mathrm{ClH} 31.558(\mu \mathrm{g} / \mathrm{h} / \mathrm{mL})$ was revealed as a more than three-fold increase as compared

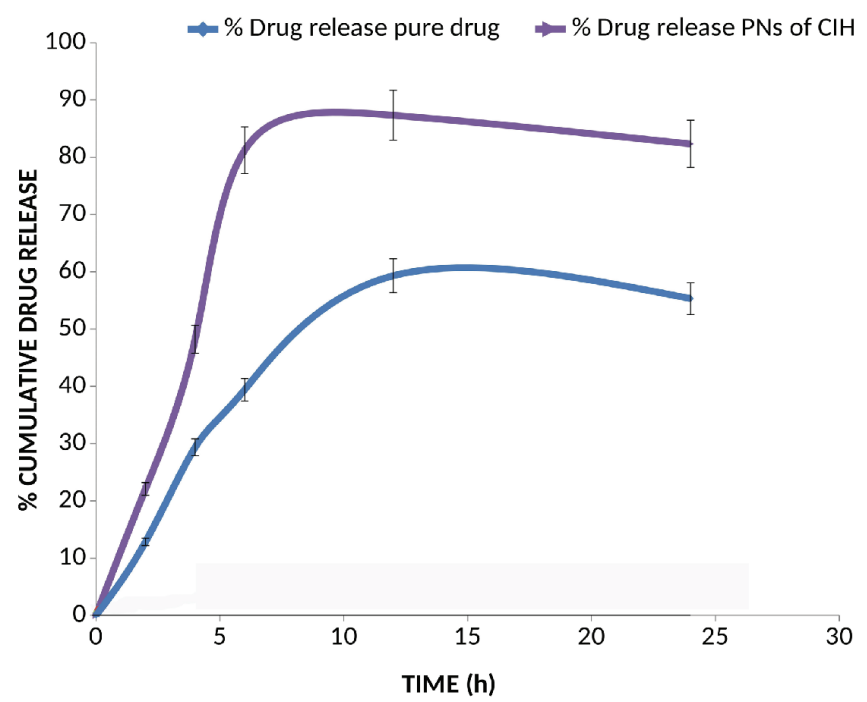

Figure 10. In vitro drug release curve of pure drug vs. optimized formulation batch

PNs: Polymeric nanoparticles, $\mathrm{ClH}$ : Cinacalcet hydrochloride

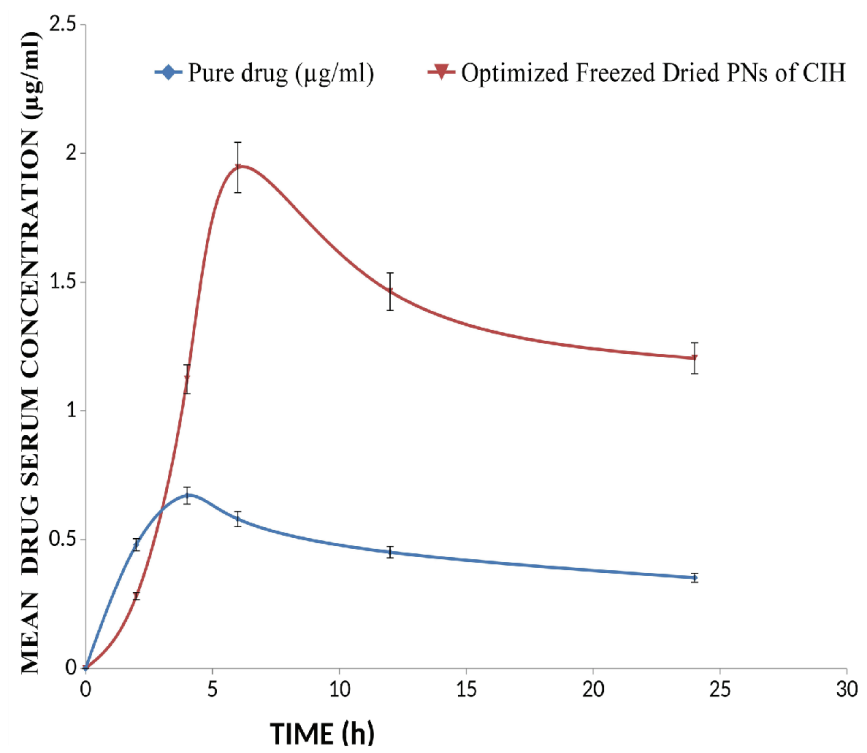

Figure 11. Serum concentration $(\mu \mathrm{g} / \mathrm{mL})$ vs. time $(h)$ curve of optimized formulation batch vs. pure-drug suspension

PNs: Polymeric nanoparticles, $\mathrm{ClH}$ : Cinacalcet hydrochloride to the AUC of the pure $\mathrm{ClH} 10.457(\mu \mathrm{g} / \mathrm{h} / \mathrm{mL})$. The rationale for the boosting up in bioavailability is its improvement in the dissolution and absorption profile of drugs through the gastrointestinal membrane. In vivo studies proved a significant elevation in the drug $\mathrm{ClH}$ absorption and permeation profile concerning optimized $\mathrm{PNs}$ of $\mathrm{ClH}$, which is evident from the distinctly superior pharmacokinetic parameter in contrast to pure drug.

\section{Accelerated stability outcomes}

The $p$ values of the design obtained during accelerated stability studies are stated in Supplement 1. The $p$ value was more than 0.05 for all the CQAs, indicating no significant change. Hence, the optimized freeze-dried PNs of $\mathrm{ClH}$ were found to satisfy the stability criteria as minimal substantial alterations in CQAs throughout the stability period.

\section{CONCLUSION}

This research instigates a systematized elaboration of PNs of a novel therapeutic for hyperparathyroidism-ClH-using a quality-by-design approach to improve drug bioavailability and sustained drug release. In the process of $\mathrm{QbD}$, the first QTTPs and CQAs were identified with proper justification. Taguchi screening resulted in primary screening, followed by orderly optimization using the BBD. The regression equation and response surface were analyzed. ANOVA model was applied in the identification of the specific appreciable model term. Optimization of freeze-dried $\mathrm{PNs}$ of $\mathrm{CIH}$ was taken by coding the high and low-value range for various CQAs. The design space identification was confirmed from the overlay plot. The optimized single dose of freeze-dried PNs of drug obtained using BBD consisted of $30 \mathrm{mg}$ of $\mathrm{ClH}, 30 \mathrm{mg}$ of PLGA, and $1.5 \% \mathrm{w} / \mathrm{v}$ of poloxamer-188. The optimized freezedried $P N$ formulation showed an optimum particle size of $147.89 \mathrm{~nm}, \mathrm{ZP}$ at $22.7 \mathrm{mV}$, EE of $69.56 \%$, and in vitro drug release of more than $75 \%$ after $24 \mathrm{~h}$. In vivo studies showed 3-folds enhancement in oral bioavailability with increased $C_{\max }$ for optimized formulation compared to a pure drug in an aqueous suspension. Accelerated stability study of optimized PNs validates the insubstantial changes in the CQAs during a stored period of 6 months, which was distinct by $p$ values for all CQAs. The conclusive justification of the present study is that an optimum combination of $30 \mathrm{mg}$ of $\mathrm{ClH}: 30 \mathrm{mg}$ of PLGA and $1.5 \% \mathrm{w} / \mathrm{v}$ of poloxamer-188 for the PLGA-based PNs of the drug may effectively be implemented to achieve the desired objective of sustained drug release and enhanced bioavailability.

\section{ACKNOWLEDGMENTS}

The authors would also like to sincerely acknowledge Dr. Sanjeeb Kumar Sahoo, Scientist-E, Institute of Life Sciences, Bhubaneswar, for providing technical support for zeta-sizer. The authors are also very thankful to Mr. Naveen Kumar Patro, Lab Technician, Central Instrumentation Facility of Roland Institute of Pharmaceutical Sciences, Berhampur, for his technical support and to Mr. Ashutosh Kumar Behera, Technical 
Superintendent, Central Instrumentation Facility, BIT, Mesra, India, for providing the facility to carry out the characterization analysis of SEM, P-XRD, TGA and DTA during our study.

\section{ETHICAL ISSUES}

All the animal studies performed in the present work were carried out before the approval of the study protocol. The pharmacokinetic study was permitted by the Animal Care Committee, Roland Institute of Pharmaceutical Sciences, Berhampur, Institutional Animals Ethics (926/PO/Re/5/06/ CPCSEA, approval no. 87). All the animal experimentation complied with the ARRIVE guidelines and were performed in association with the UK Animals (Scientific Procedures) Act, 1986 and connected guidelines, EU Directive 2010/63/EU for animal experiments.

Conflict of interest: No conflict of interest was declared by the authors. The authors are solely responsible for the content and writing of this paper.

\section{REFERENCES}

1. Peer D, Karp JM, Hong S, Faro Khzad OC, Margalit R, Langer R. Nanocarriers as an emerging platform for cancer therapy. Nat Nanotechnol. 2007;2:751-760.

2. Davis ME,Chen Z, Shin DM. Nanoparticle therapeutics: an emerging treatment modality for cancer. Nat Rev Drug Discov. 2008;7:771-782.

3. Quintanar-Guerrero D, Allemann Fessi EH, Doelker E. Preparation techniques and mechanisms of formation of biodegradable nanoparticles from preformed polymers. Drug Dev Ind Pharm. 1998;24:1113-1128.

4. Bhanoji Rao ME, Swain S, Patra CN, Mund SP. Formulation design, optimization and characterization of eprosartanmesylate nanoparticles. Nanosci Nanotech-Asia. 2018;8:2130-2143.

5. Kreuter J. Nanoparticles-a historical perspective. Int J Pharm. 2007;331:110.

6. Soppimath KS, Aminabhavi TM, Kulkarni AR, Rudzinski WE. Biodegradable polymeric nanoparticles as drug delivery devices. J Control Release. 2001;70:1-20.

7. Shenoy DB, Amiji MM. Poly (ethylene oxide)-modified poly-(epsiloncaprolactone) nanoparticles for targeted delivery of tamoxifen in breast cancer. Int J Pharm. 2005;293:261-270.

8. Glen A. The impact of nanotechnology in drug delivery: global developments, Market Analysis Future Prospects, 2005. Last Accessed Date: 31.03.09. Available from: http://www.nanomarkets.com

9. Safra T, Muggia F, Jeffers S, Tsao-Wei DD, Groshen S, Lyass O, Henderson R, Berry G, Gabizon A. Pegylated liposomal doxorubicin (doxil): Reduced clinical cardio toxicity in patients reaching or exceeding cumulative doses of $500 \mathrm{mg} / \mathrm{m}^{2}$. Ann Oncol. 2000;8:1029-1033.

10. Schroeder U, Sommerfeld P, Ulrich S, Sabel BA. Nanoparticle technology for delivery of drugs across the blood-brain barrier. J Pharm Sci. 1998;87:1305-1307.

11. Raghuvanshi RS, Katare YK, Lalwani K, Ali MM, Singh O, Panda AK. Improved immune response from biodegradable polymer particles entrapping tetanus toxoid by use of different immunization protocol and adjuvants. Int J Pharm. 2002;245:109-121.
12. Kreutera J, Petrov VE, Kharkevich DA, Alyautdin RN. Influence of the type of surfactant on the analgesic effects induced by the peptide dalargin after its delivery across the blood- brain barrier using surfactant-coated nano-particles. J Control Release. 1997;49:81-87.

13. Allemann E, Gurny R, Christophe JL. Biodegradable nanoparticles- from sustained release formulations to improved site specific drug delivery. $J$ Control Release. 1996;39:339.

14. Moffitt M, Khougaz K, Eisenberg A, Micellization of ionic block copolymers. Acc Chem Res. 1996;29:95-102.

15. Sushant SK, Yogesh M, ChoudhariNazma NI, Vishnukant M. Polymeric micelles: authoritative aspects for drug delivery. Designed Monomers and Polymers. 2012;15:465-521.

16. Burt HM, Zhang X, Toleikis P, Embree L, Hunter WL. Development of copolymers of poly (dl-lactide) and methoxypolyethylene glycol as micellar carriers of paclitaxel. Colloids Surf B Biointerfaces. 1999;16:161-171.

17. Xiaoqing $\mathrm{XU}$, Guoguang $\mathrm{C}$, Yaning LI, Jingjing $\mathrm{W}$, Jun $\mathrm{Y}$, Lili R. Enhanced dissolution and oral bioavailbility of cinacalcet hydrochloride nanocrystals with no food effect. Nanotechnol. 2019;30:55-102.

18. Yoo HS, Park TG. Biodegradable polymeric micelles composed of doxorubicin conjugated PLGA-PEG block copolymer. J Control Release. 2001;70:63-70.

19. Jain RK, Stylianopoulos T. Delivering nanomedicine to solid tumors. Nat Rev Clin Oncol. 2010;7:653-654.

20. Lammers T, Kiessling F, Hennink WE, Storm G. Drug targeting to tumors: principles, pitfalls and (pre) clinical progress. J Control Release. 2012;161:175-187.

21. Bae YH, Yin H. Stability issues of polymeric micelles. J Control Release. 2008;131:2-4.

22. Read ES, Armes SP. Recent advances in shell cross-linked micelles. Chem Commun (Camb). 2007:3021-3035.

23. Deng C, Jiang Y, Cheng R, Meng F, Zhong Z. Biodegradable polymeric micelles for targeted and controlled anticancer drug delivery: promises, progress and prospects. Nano Today. 2012;7:467-480.

24. Abdollahi S, Lotfipour F. PLGA-and PLA -based polymeric nanoparticles for antimicrobial drug delivery. Biomed Int. 2012;3:1-11.

25. Burlington MA. 2014 Nurse's drug handbook. (13 th ed). Burlington, Massachusetts: Jones \& Bartlet Learning; 2014.

26. Yousaf F, Charytan C. Review of cinacalcet hydrochloride in the management of secondary hyperparathyroidism. Ren Fail. 2014;36:131138.

27. Padhi D, Harris R. Clinical pharmacokinetic and pharmacodynamic profile of cinacalcet hydrochloride. Clin Pharmacokinet. 2009;48:303311.

28. Swain S, Parhi R, Jena BR, Babu SM. Quality by design: concept to applications. Curr Drug Discov Technol. 2019;16:240-250.

29. Podczeck F. Pharmaceutical Experimental Design. In: Lewis GA, Mathieu D, and R. Phan-Tan-Lu, eds. Boca Raton, Florida: CRC Press; 1999:498.

30. Box GEP, Wilson KB. On the experimental attainment of optimum conditions. J Royal Stat Soc Ser B. 1951;1:1-45.

31. Swain S, Jena BR, Madugula D, Beg S. Application of Quality by Design Paradigms for Development of Solid Dosage Forms. In: Beg S, Hasnain S, eds. Pharmaceutical Quality by Design; Principles and Applications. (1 ${ }^{\text {st }}$ ed). Cambridge, Massachusetts: Elsevier Academic Press; 2019:109130. 
32. Box GEP, Behnken DW. Some new three level designs for the study of quantitative variables.Technometrics. 1960;2:455-475.

33. Panigrahi KC, Patra CN, Rao MEB. Quality by design enabled development of oral self- nanoemulsifying drug delivery system of a novel calcimimetic cinacalcet $\mathrm{HCl}$ using a porous carrier: in vitro and in vivo characterization. AAPS Pharm Sci Tech. 2019;20:216.

34. Neupane YR, Sabir MD, Ahma N, Ali M, Kohli K. Lipid drug conjugate nanoparticle as a novel lipid nanocarrier for the oral delivery of decitabine: ex vivo gut permeation studies. Nanotechnology. 2013;24:415102.

35. Hu C, Rhodes DG. Proniosomes: a novel drug carrier preparation. Int J Pharm.1999;185:23-35.

36. GregorC Mc, Bines E. The use of high-speed differential scanning calorimetry (Hyper- DSC) in the study of pharmaceutical polymorphs. Int J Pharm. 2007;350:48-52.

37. Didem AS, Muharrem S,Johanna GW, Frank S, Thomas S. Nano structured Biomaterials and applications. J of Nanomater. 2016;13.

38. Dynamic Light Scattering Particle Size and Zeta Potential Analyzer. Last Accessed Date: 03.11.2015. Available from: https://www.iitk.ac.in/ dordoldn/dynamic-light-scattering-particle-size-and-zeta-potentialanalyzer

39. Cruz CN, Tyner KM, Velazquez L, Hyams KC, Jacobs A, Shaw AB, Jiang W, Lionberger R, Hinderling P, Kong Y, Brown PC, Ghosh T, Strasinger C, Suarez-Sharp S, Henry D, Van Uitert M, Sadrieh N, Morefield E. CDER risk assessment exercise to evaluate potential risks from the use of nonmaterial's in drug products. AAPS J. 2013;15:623-628.

40. Langer R. New methods of drug delivery. Science. 1990;249:1527-1533.

41. Arifin DY, Lee LY, Wang $\mathrm{CH}$. Mathematical modeling and simulation of drug release from microspheres: implications to drug delivery systems. Adv Drug Deliv Rev. 2006;58:1274-1325.

42. Siepmann J, Siepmann F. Mathematical modeling of drug delivery. Int J Pharm. 2008:364:328-343.

Supplement 1. Drug release, particle size, zeta potential, and PDI of optimized PN formulations at accelerated stability conditions

\begin{tabular}{|c|c|c|c|c|}
\hline Time (months) & QT24\% (cumulative drug release) & Particle size $(\mathrm{nm})$ & Zeta potential $(\mathrm{mV})$ & PDI \\
\hline 0 & 76.945 & 147.898 & 22.7 & 0.398 \\
\hline 1 & 73.394 & 168.493 & 18.342 & 0.232 \\
\hline 2 & 71.452 & 182.312 & -13.41 & 0.421 \\
\hline 3 & 68.341 & 168.301 & -12.311 & 0.311 \\
\hline 6 & 66.311 & 190.451 & -22.212 & 0.390 \\
\hline$P$ value $\alpha \leq 0.05=$ significant & 0.072 & 0.263 & 0.217 & 0.481 \\
\hline
\end{tabular}

PDI: Polydispersity index, PN: Polymeric nanoparticle
43. Lin SB, Hwang KS, Tsay SY, Cooper SL. Segmental orientation studies of polyether polyurethane block copolymers with different hard segment lengths and distributions. Colloid Polym Sci. 1985;263:128-140.

44. Carter M, Jennifer S. In Guide to Research Techniques in Neuroscience. ( $2^{\text {nd }}$ ed). Marcel Dekker Inc; USA; 2015.

45. Peter Christoper GV, Vijaya Raghavan C, Siddharth K, Siva Selva KM, Hari Prasad R. Formulation and optimization of coated PLGA- zidovudine nanoparticles using factorial design and in-vitro in-vivo evaluations to determine brain targeting efficiency. Saudi Pharm. J 2014;22:133-140.

46. Haines PJ. Principles of thermal analysis and calorimetry, RSC paperbacks, Royal Soc of Chem. 2002:1-9.

47. Nakashima D, Takama H, Ogasawara $Y$, Kawakami T, Nishitoba T, Hoshi S, Uchida E, Tanaka H. Effect of cinacalcet hydrochloride, a new calcimimetic agent, on the pharmacokinetics of dextromethorphan: in vitro and clinical studies. J Clin Pharmacol. 2007;47:1311-1319.

48. Differential thermal Analysis. Last Accessed Date: 01.12.2018. Available from: https://www.sciencedirect.com/topics/medicine-and-dentistry/ differential-thermal-analysis.

49. Janga KY, Jukanti R, Velpula A, Sunkavalli S, Bandari S, Kandadi $P$, Veerareddy PR. Bioavailability enhancement of zaleplon via proliposomes: role of surface charge. Eur J Pharm Biopharm. 2012;80:347-357.

50. Legrand P, Lesieur S, Bochot A, Gref R, Raatjes W, Barratt G. Influence of polymer behaviour in organic solution on the production of polylactide nanoparticles by nanoprecipitation. Int J Pharm. 2007;344:33-43.

51. Chorny M, Fishbein I, Danenberg HD, Golomb G. Lipophilic drug loaded nanospheres prepared by nanoprecipitation: effect of formulation variables on size, drug recovery and release kinetics. J Conrol Release. 2002;83:389-400.

52. Rostamizadeh AHK, Salari D, Hamidi M. Preparation of biodegradable nanoparticles of tri- block PLA-PEG-PLA copolymer and determination of factors controlling the particle size using artificial neural network. J Microencapsul. 2011; 28:406-416. 